\title{
THE SOCIAL TRANSFORMATION OF VICE
}

\author{
Jerome H. SKOLNick*
}

INTRODUCTION

What is vice, and how does it differ from crime? Why does society's conception of vice shift over time? Which social and cultural factors lead to reassessments of the moral blameworthiness inherent in the concept of vice? This article considers these questions and argues that, because vice both represents and results from moral ambivalence, it is distinguishable from the concept of crime; ${ }^{1}$ vice is continually subject to reevaluation. Attitudes toward vice are thus inherently unstable. Further, moral ambivalence varies, depending upon how the particular characteristics of a vice map on to basic cultural values. ${ }^{2}$ Values are often inconsistent with one another and drift over time in their perceived importance, taking on different significance from one decade to the next. Society's evaluation of social policies regarding vice are heavily influenced by these shifting values and, thus, limit the possibility of rational and scientific policy analysis.

\section{Copyright $\mathcal{C} 1988$ by Law and Contemporary Problems}

* Clair Clements Dean's Professor of Law, Jurisprudence and Social Policy Program, University of California at Berkeley.

1. This is a sociological rather than a jurisprudential analysis. A jurisprudential analysis advances a thesis about how the law ought to treat vice. A sociological analysis tries to understand how societal factors influence jurisprudential judgments. The most traditional jurisprudential thesis about the relation between crime and vice was advanced by Sir James Fitzjames Stephen. Stephen argued that the object of the criminal law is, or includes, "promoting virtue" and "preventing vice." Accordingly, he believed that criminal law "ought to put a restraint upon vice not to such an extent merely as is necessary for definite self protection but generally on the ground that vice is a bad thing." J. Stephen, Liberty, EQuality, Fraternity 147-48 (1873). H.L.A. Hart is sharply critical of Stephen's view, arguing that it implies that law should make punishable "actions which are condemned by society as immoral, even if they are not harmful." H. HaRT, LaW, LiberTy and Morality 36 (1963). Hart characterizes Stephen's argument as a non sequitur because Stephen fails to distinguish between the question of what conduct ought to be punished from the question of how severely such conduct ought to be punished. Hart writes, "[b]ut those who concede that we should attempt to adjust the severity of punishment to the moral gravity of offences are not thereby committed to the view that punishment for mere immorality is justified." Id. at 37.

2. Among these values are physical health, public safety, fostering the moral development of children, autonomy (including freedom from drug dependence), control over information about oneself, the ability to discharge family and social responsibilities, the right to self-fulfillment through sensual pursuits, economic opportunity, and the right to be free from state intrusions on personal freedom. 


\section{II}

\section{Vice and Moral Ambivalence}

What is vice? It is clearly not enough to define vice, as leading dictionaries do, as evil or immoral conduct. ${ }^{3}$ The idea of vice connotes more than immorality alone. The term implies pleasure and popularity, as well as wickedness. Behaviors which offend the moral views of ordinary citizens, such as murder and robbery, are not pleasurable for them; only a small proportion of the population are attracted to those activities. Conversely, other undertakings, such as skiing or eating ice cream, are pleasurable but not immoral. Vices such as gambling, drugs, adultery, and prostitution may be both gratifying and wicked.

Neither is vice synonymous with what sociologists would consider deviance. Deviance embraces conduct that breaks social norms of propriety but is not necessarily evil or immoral. Deviant behavior can range from breaches in civility such as picking one's nose in public, to breaches of physical appearance norms associated with a physical deformity or handicap. ${ }^{4}$ To be considered as a vice, however, conduct must rise to a minimal level of moral culpability. Such culpability may be explained in both utilitarian and deontological terms. For example, some may argue that one has a duty not to gamble because material rewards should derive from hard work and not from fortuity. Others may argue that gambling results in serious harm to oneself and to one's family. Jeremy Bentham argued that heavy risk taking, which he called "deep play," is morally wrong on utilitarian principles. ${ }^{5}$ When betting one's last thousand pounds, the pain of losing would exceed the pleasure of winning; therefore, heavy gambling, according to Bentham, is immoral. ${ }^{6}$

Vice implies moral ambivalence, that is conduct that a person may enjoy and deplore at the same time. As a corollary, moral ambivalence generates controversy over public policy concerning certain activities. If an activity is clearly accepted as immoral, as are robbery and burglary, no difficult public policy issue arises because no organized segment of the polity favors the legalization of theft. On the other hand, people who enjoy gambling, marijuana, and prostitution often advocate legalization. ${ }^{7}$ Even where no one advocates legalization, and the conduct remains prohibited, laws may be defied by huge numbers of participants. ${ }^{8}$

3. See, e.g., Webster's New Collegiate Dictionary 1303 (1977).

4. Many illustrations are to be found in the work of E. Goffman. In particular, see E. GorfmaN, Stigma: Notes on the Management of Spoiled Identity 140-47 (1963).

5. J. Bentham, Theory of Legislation 102-03 (1876).

6. Id.

7. For example, groups representing both marijuana users (the National Organization for Reform of Marijuana Laws) and groups with high rates of use (the National Students Association) lobby for reduced penalties and new legislation. See generally J. Himmelstein, The Strange Career of Marijuana: Politics and Ideology of Drug Control in America 112 (1983).

8. In 1982, an estimated 20 million people in the United States used marijuana at least once a month and 100.2 million had used alcohol at least once within the month prior to being surveyed. Drug Abuse Police Office, Office of Policy Development, The White House, 1984 National Strategy for Prevention of Drug Abuse and Drug Trafficking 17-18 (1984). 
Moral ambivalence may be further understood as an elaboration of the theory of sociological ambivalence advanced by Robert K. Merton. ${ }^{9}$ Merton extended traditional theories of psychological ambivalence to the sociological realm. ${ }^{10}$ Unlike psychological ambivalence, which refers to mixed feelings toward persons or objects, sociological ambivalence "refers to incompatible normative expectations of attitudes, beliefs, and behavior assigned to" a role or status. " For example, the expectations of moral conduct demanded of the physician in the therapist role differs from, and may conflict with, that of the physician in the role of experimental researcher. ${ }^{12}$

Moral ambivalence, however, refers less to incompatible role expectations than to incompatible expectations of attitude, belief, and behavior assigned to conduct norms. Will Rogers nicely summarized the moral ambivalence of the Prohibition era.

[Rogers commented,] "If you think this country ain't Dry, you just watch 'em vote; and if you think this country ain't Wet, you just watch "em drink." It was E.B. White who slyly proposed in the 1920's that the federal government nationalize speakeasies: "In that manner the citizenry would be assured liquor of a uniformly high quality, and the enormous cost of dry enforcement could be met by profits from the sale of drinks." 13

Because vice implies moral ambivalence, its conduct norms are especially subject to change. Shifting definitions of vices are often interpreted as a function of political affiliation and preference, rather than cultural contradiction. Experience, however, suggests otherwise. For example, in 1964, no state lotteries existed in the United States, but today twenty-six are in operation. ${ }^{14}$ These are endorsed by both Democrats and Republicans. ${ }^{15}$

Charles Rangel, a Democratic congressman from New York, and chairman of the House Select Committee on Narcotics Abuse and Control, is one of Congress's most enthusiastic spokesmen favoring the "War on Drugs." That symbolism has also been endorsed by the Reagan Administration. ${ }^{16}$

In yet another "vice" arena, Republicans and Democrats alike may engage in adultery while deploring the practice. ${ }^{17}$ Even selective enforcement in this area suggests moral ambivalence. Most states retain prohibitions against

9. R. Merton, Sociological Ambivalence and Other Essays (1976).

10. Id. at 4-6.

11. Id. at 6 .

12. Id.

13. M. Kammen, People of Paradox: An Inquiry Concerning the Origins of American Civilization 268 (1972) (quoting Rogers and White). 1 .

14. 26 States Now Running Lotteries to Ease Budgetary Burdens, N.Y. Times, Feb. 16, 1988, at B5, col.

15. Both Republican and Democrat dominated state assemblies have passed legislation establishing lotteries. The Development of The Law of Gambling: $1776-1976$, at 679 (1977) (project by Cornell University Law School).

16. See, e.g., Werner, Senate Demos Want Top-Level Drug Fighter-Cabinet Level Post, N.Y. Times, Apr. 14, 1987, at Al8, col. 1 .

17. Lynn Altwater notes that most Americans who engage in adultery at some point in their lives also say, when asked, that they disapprove of extramarital sex. L. Altwater, The Extramarital Connection: Sex, Intimacy, and Identity 1 (1982). 
adultery, which rarely, if ever, are enforced. ${ }^{18}$ Therefore, party affiliation divides society for many issues, but not necessarily on issues of vice. Accordingly, we need to reach beyond surface politics to understand how moral ambivalence affects social acceptance of marginal conduct norms.

Scientific judgments might seem to offer a firmer basis for grounding such norms, but that is not so. Objective research assessments are rarely the sole or even major factor in identifying and developing policies regarding risky or unacceptable behavior. ${ }^{19}$ Thus, despite objective evidence of health hazards associated with alcohol and cigarette consumption, their use is legalized. The law, therefore, does not necessarily follow the dictates of science. Neither law nor science can be counted on to govern conduct. According to the Wickersham Commission, the popularity of alcohol consumption increased among identifiable social groups during Prohibition, as the speakeasy began to symbolize high social status. ${ }^{20}$ Therefore, we need to reach beyond both politics and scientific assessments of harm to understand the processes by which definitions of vice change over time. To help understand the social transformation of vice, we should explore issues of social structure, conflicting community values, and ideology. ${ }^{21}$

\section{III}

\section{DURKheimian ANalysis}

It is useful to develop this argument with a brief introduction to the classical thinking of Emile Durkheim because his vision of society and morality supports the analysis that follows. ${ }^{22}$ Durkheim offers two fundamental theses-the common conscience thesis and the deviance property argument. The common conscience thesis presents the counterintuitive observation that criminal conduct defines a sense of community. The deviant actor offends the sensibility of ordinary people who, through gossip and conversation, both reflect and define a "common conscience" of acceptable behavior. ${ }^{23}$ Crime is

18. For commentary on the infrequent enforcement of state adultery laws, see G. MUELLER, Sexual Conduct and the Law 36 (2d ed. 1980); B. Anthony Morosco, The Prosecution and Defense of Sex Crimes 1-14.4 to 1-14.5 (1987); D. MacNamara \& E. Sagarin, Sex, Crime, and the LAW 192 (1977).

19. This is the general thesis of M. Douglas \& A. Wildavsky, Risk and Culture (1982).

20. 1 U.S. National Commission on Law Observance and Enforcement, Enforcement of the Prohibition Laws 313 (1931); Gerstein, Alcohol Use and Consequences, in Alcohol and Public Policy: Beyond the Shadow of Prohibition 182, 194-95 (1981) (reported liver disease decreased during Prohibition, suggesting that very heavy drinking was reduced). Whether this holds true for moderate drinking depends, of course, on the relationship between heavy drinking and moderate or light drinking during a period when it is prohibited. Possibly, Prohibition popularized drinking, but the relative unavailability of alcohol produced fewer heavy drinkers.

21. For a discussion of symbolic politics, see McConahay, Pornography: The Symbolic Politics of Fantasy, Law \& Contemp. Probs., Winter, 1988, at 31.

22. The best overall introduction to Emile Durkheim's sociology is S. Lukes, Emile Durkheim: His Life and WORK (1973). I am relying primarily on English translations of E. DurkhEIM, The Division of Labor in Society (1933) [hereinafter Division of Labor], and E. Durkheim, The Rules of Sociological Method (1938) [hereinafter The Rules] (a response to critics of The Division of LABOR).

23. Division OF LABOR, supra note 22 , at 73 . 
normal, inevitable, and paradoxically beneficial since it defines the boundaries of the moral order. ${ }^{24}$ Durkheim observed that crime was "an integral part of all healthy societies." 25 In fact, crime would be present even in a society of saints where minor infractions might be taken more seriously. ${ }^{26}$

The idea of a common conscience may sound antiquated, but it resonates in a contemporary phrase of Kent Greenawalt. ${ }^{27}$ He observed that theories of the justification of punishment "do not usually stray too far from the reflective moral views of ordinary citizens." 28 Durkheim's "common conscience" and Greenawalt's "reflective moral views of ordinary citizens" capture a similar idea, namely a community of commonly held moral views. The idea of vice is not incompatible with this notion of common conscience. The case of vice, however, suggests a core and a periphery to the idea of common conscience. In other words, although Durkheim never actually discusses vice, the more severe the moral apprehensions of the community, the more extensive the range of behavior that might be regarded as vice. This relationship can be seen most clearly in a morally homogeneous society, where members form a consensus or core opinion about morality. In a pluralistic society, however, reflective members may well express different evaluations regarding the seriousness of vice. They do not share common views at the periphery despite their subscription to a widely shared core morality. For example, the moral views of churches that preach total abstinence from alcohol is indeed different from those of the legendary publishers who enjoy a three-martini lunch. At the same time, at the core, both might agree that the crime of armed robbery is more serious than theft. For this conduct, it makes sense to employ the concept of "just desert." But it is not clear what moral intuition governs the idea of a just desert for smoking a marijuana cigarette or betting illegally on the Superbowl. In a pluralistic society, a consensus cannot be assumed at the periphery.

This observation leads to a related Durkheimian thesis, which might be called the deviance property argument. ${ }^{29}$ According to this position, the severity with which a community defines, grades, and represses deviant conduct does not follow from the nature of the harm produced. As Durkheim writes, "[w]e cannot draw up a list of sentiments whose violation constitutes a crime; they distinguish themselves from others only by this trait, that they are common to the average mass of individuals of the same society."30 Modern writers in the deviance property tradition, such as Howard S. Becker, argue

\footnotetext{
24. The Rules, supra note 22 , at 67-70.

25. The Rules, supra note 22, at 67 . For a more recent, albeit classic, elaboration of this idea, see K. Erikson, Wayward Puritans: A Study in the Sociology of Deviance (1966).

26. The Rules, supra note 22, at 68-69.

27. Greenawalt, Punishment, in 4 Encyclopedia of Crime and Justice 1336, 1345 (1983).

28. Id.

29. Division of LABOR, supra note 22, at 73.

30. Id.
} 
that a deviant is someone to whom the label of offender has successfully been applied. 31

The deviance property thesis asserts that different communities may be distinguished on the basis of their different assessments of the moral blameworthiness of conduct. Further, as suggested above, varying and even competing assessments may exist within large and culturally plural communities. The deviance property thesis does not apply only to marginal behavior. Harm and punishment are not necessarily connected. Durkheim points out that a killing in wartime is not defined as murder but is excused. Similarly, advocates of decriminalization of vices, such as drugs and prostitution, tend to define them as excusable, as "crimes without victims" or at least as activities about which individuals in a free society enjoy a moral right to exercise a choice. ${ }^{32}$ In contrast, those who favor prohibition of such vices see them as harmful to the individual and society, and, therefore, deserving punishment. ${ }^{33}$

The common conscience and the deviance property theses tell much about centrality and variation in the definition of immorality. Neither, however, tells much about shifting definitions, the dynamic processes by which conduct is transformed into more or less acceptable behavior. Moreover, neither theory tells us how marginal conduct becomes regarded as a serious crime. To better understand dynamic shifts in social definitions of conduct we need to begin to explore factors which might account for the development of moral intuitions. ${ }^{34}$

31. For one modern writer, see H. Becker, Outsiders: Studies in the Sociolocy of Deviance 3-8 (1973).

32. There are numerous decriminalization advocates in both law and sociology. In the legal tradition, one can identify H. Hart, supra note $1 ;$ H. Packer, The Limits of the Criminal Sanction (1968); N. Morris \& G. Hawkins, The Honest Politician's Guide to Crime Control (1970); J. Kaplan, Marijuana: The New Prohibition (1972). In sociology, the leading scholars of this position include E. Schur, Crimes Without Victims (1965); E. Schur \& H. Bedau, Victimless Crimes: Two Sides of the Controversy (1974); H. Becker, Outsiders (1963); E. Goode, The Marijuana Smokers (1970).

33. The classic advocates of this position are H. Anslinger \& $\mathrm{W}$. Tomkins, The Traffic in NARCoTics (1953). Goode, however, argues that the "facts" of marijuana's impact on individuals are culturally determined.

Conceptions of true and false are extravagantly refracted through social and cultural lenses to such an extent that the entire notion of empirical truth becomes irrelevant. True and false become, in fact, what dominant groups define as true and false; its very collectivity establishes legitimacy. A pro- or anti-marijuana stance reflects a basic underlying attitudinal syndrome, ideological in character, that is consonant with its drug component. Prior to being exposed to attitudes or 'facts' about marijuana, the individual has come to accept or reflect fundamental points of view which already lead him to apprehend the reality of marijuana in a definite manner. These ideological slants are not merely correlates of related and parallel attitudes. They are also perceptual screens through which a person views empirically grounded facts.

E. Goode, supra note 32 , at 58.

34. Of course, Durkheim implies a theory of moral change predicated on changes in the division of labor. Division of LABOR, supra note 22, at 400-01. He recognizes that such factors as industrial and commercial crises and the conflict between capital and labor will produce what he calls an "anomic" division of labor. Id. Nevertheless, his most important conclusion relates to the relation between society and morality. He argues that moral conceptions are grounded in social relationships. Id. at 399. Durkheim concludes: 


\section{Moral Conflict}

When a society has a moral conflict - that is, a clash of moral intuitions-as to whether a form of conduct is a vice, shifting official views of the conduct are more likely to occur. A change in official view is unlikely when consensus prevails. Change occurs when consensus declines. The relation between moral conflict and shifting official proscription is nicely illustrated by the legal history of gambling, which is rooted in the discord between aristocratic and puritan values.

\section{A. Rise and Fall of Puritan Values}

Aristocrats, members of the landed gentry, were characterized by their freedom from work. ${ }^{35}$ They did not till the fields nor supervise its tilling. Rather than working, English noblemen learned to dance, joust, ride horses, deal cards, and roll dice. ${ }^{36}$ The Puritans, by contrast, discouraged idle play. ${ }^{37}$ Puritans would engage in exercise to improve health and character, but not just to have fun. ${ }^{38}$ Gambling was inconsistent with the Puritan ethic encouraging productive use of time. ${ }^{39}$ Thus, in 1657 , to discourage gambling after the Cromwell revolution, the Puritans enacted legislation allowing losers to sue for the recovery of twice their gambling losses. ${ }^{40}$

In 1660 , when the Stuart monarchy returned to power, it abrogated all such legislation enacted under the Puritans. ${ }^{41}$ According to Trevelyan, Queen Anne popularized gambling for both sexes. ${ }^{42}$ Consequently, "[t]he

Society is not, then, as has often been thought, a stranger to the moral world, or something which has only secondary repercussions upon it. It is, on the contrary, the necessary condition of its existence. It is not a simple juxtaposition of individuals who bring an intrinsic morality with them, but rather man is a moral being only because he lives in society, since morality Id. consists in being in solidarity with a group and varying with this solidarity.

35. Carl Bridenbaugh describes the diary of one of the lesser sporting gentry of West Lancashire during 1617-18, who

never missed the two Sunday services, listened to forty sermons, three of them by different bishops, and thought he had acquitted himself very well with his maker. In the same period he also participated in sixteen fox hunts, ten for stags, two for bucks, two for otter, two for hares, and one for badgers, besides spending four days each shooting grouse and fishing, and two with the falcons.... On Sabbath evenings, Assheton and his wife frequented an alehouse and saw no sin in it, nor did the many male and female companions who joined them there. Indoors his recreation consisted chiefly of playing at shove-groat or dice with his pious cronies (once all night), or some "other friendlie sports."

C. Bridenbaugh, Vexed and Troubled Englishmen 1590-1642, at 113 (1967).

36. " 'When we do not hunt, we hawke,' Viscount Conway told a friend . . 'the rest of the time is spent in tennis, chesse, and dice, and in a worde we eat and drinke and rise up to play; and this is to live like a gentleman; for what is a gentleman but his pleasure'." C. BRIDEnBaugh, supra note 35, at 112. And, adds Brindenbaugh, "play they did, as long and hard as the station in life allowed." Id.

37. Id. at 115 .

38. Id.

39. Id.

40. The Development of the Law of Gambling, supra note 15 , at 10 .

41. Id. at 11 .

42. G. Trevelyan, English Social History 314 (1965). 
expenses of gambling . . . burdened estates with mortgages which proved a heavy clog on agricultural improvement and domestic happiness. Immense sums of money changed hands over cards and dice."43 The Gaming Act of 1710, known popularly as the Statute of Anne, made gambling debts unenforceable as a matter of public policy and was introduced by the phrase, "Whereas the Laws now in force for preventing the Mischiefs which may happen by Gaming have not been found sufficient for that Purpose." 44 Many young aristocrats destroyed themselves and their family fortunes in the eighteenth and nineteenth centuries. ${ }^{45}$ William Hawkins, the noted jurist, wrote of the "vice of gaming" 46 and described it as an offense "against the political economy of the state," inasmuch as it leads "to fraud and thieving among the lower classes and to ruin with the opulent." 47 From the midseventeenth century onward, continuous conflict existed within England between the carefree and hedonistic values of the aristocracy and the sterner code prevailing in Puritan circles. Despite Puritan sentiment, however, in 1776 Parliament sanctioned gambling in the form of lotteries to shore up the public fisc. ${ }^{48}$ At the same time, numerous other lotteries were authorized between the sixteenth and nineteenth centuries. ${ }^{49}$ The 1933 Royal Commission on Lotteries and Betting found that by 1776, the lottery, which had first been adopted "as an expedient to meet some special need," 50 had become "virtually an annual event." 51

Similarly, the Jamestown settlement in America could not have survived without a lottery. ${ }^{52}$ The King granted to the Virginia Company a charter authorizing a lottery to further the process of colonization. ${ }^{53}$ During the fiscal year ending in 1621 , Virginia had a total operating budget of 17,800 pounds, including lottery profits totaling 8,000 pounds. ${ }^{54}$ Lotteries were regarded as the "reall and substantiall food, by which Virginia hath been nourished." 55 No American government entity, with the possible exception of post World War II Nevada or nineteenth century Louisiana, had ever been so dependent on gambling revenues for so large a proportion of its budget. ${ }^{56}$

43. Id.

44. Gaming Act of 1710 (Statute of Anne) 9 Anne, c. 14 (1710).

45. H. Blyth, Hell and Hazard or William Crockford versus the Gentlemen of England (1969). Blyth comments that: "the gambling mania, and much of the wild and dissolute behaviour of the Restoration, Regency and early Victorian rakes, were the outcome of lack of purpose in the lives of young men who suffered from too much leisure and too much wealth, with too little opportunity to prove their manhood." Id. at $\mathrm{x}$.

46. The Development of the Law of Gambling, supra note 15.

47. W. Hawkins, a Treatise of the Pleas of the Crown, or a System of the Principal Matters Relating to that Subject, Digested under Their Proper Heads 720 (5th ed. 1771).

48. Royal Commission on lotteries and Betting, Final Report, 1932-1933, CMND, No. 4341, at 6 [hereinafter Royal Commission].

49. Id. at 8 .

50. Id. at 6 .

51. Id.

52. J. Ezell, Fortune's Merry Wheel: The Lottery in America 4 (1960).

53. Id.

54. Id. at 8-9.

55. Id. at 8 .

56. Id. at 4 . 
In 1826, England abolished state lotteries. ${ }^{57}$ This followed Parliament's conclusion that, "[n]o [other] mode of raising money appears so burdensome, so pernicious, and so unproductive." 58 In America, lottery opposition was reinforced by the success of the Puritan view in England. ${ }^{59}$ Denunciation of lotteries by Quaker and Puritan spokesmen spread throughout the Northeast. ${ }^{60}$ The South began to feel the pressure by the 1840's and 1850 's. ${ }^{61}$ After the Civil War, only Louisiana retained its lottery, which became infamous because most of its revenues were drawn from other states prohibiting lotteries. ${ }^{62}$ Congress enacted a law making it a federal crime to transport lottery materials across state lines. ${ }^{63}$ Even Louisiana, in response to national opposition, discontinued its own lottery before the turn of the century. ${ }^{64}$ Thus, with the approach of the twentieth century, government-run lotteries disappeared from American life. ${ }^{65}$ The Puritans had triumphed.

Puritans' perceptions of the lottery dominated for the next sixty-four years. Neither the First World War, the Roaring Twenties, the Depression, nor the Second World War produced a movement to reinstate the lottery as a source of revenue. The federal government needed revenue during World War II but was apparently unwilling to resort to anything as controversial as lotteries. Evidently, the government preferred debt through war bonds, rather than lotteries. Apparently lotteries were not considered because they must have been morally unacceptable. In light of the financial success of current state lotteries, it seems plausible that a wartime lottery would have raised sizable revenue.

\section{B. Fiscal Needs and Pressures}

No state-sponsored lotteries appeared in the United States until 1964 when New Hampshire introduced a sweepstakes to benefit local education programs. ${ }^{66}$ New Hampshire was morally conservative, and so the sweepstakes generated conflicting responses. ${ }^{67}$ The lottery promised to finance education without taxes. ${ }^{68}$ On the other hand, state-sanctioned gambling offended many New Englanders who felt the government should not promote idle amusements. ${ }^{69}$ Ultimately, "sin" taxation resolved moral ambivalence. New Hampshire could have its fiscal cake and eat it too. "Sin" taxes raised revenue-the state had no sales or income taxes but derived more

\footnotetext{
57. Royal Commission, supra note 48 , at 7.

58. Id.

59. J. EzELL, supra note 52, at 191-92.

60. Id. at $190-98$.

61. Id. at 223 .

62. Id. at 241-51.

63. Act of 1895, ch. 191, 28 Stat. 963 (not codified into U.S. Code); Champion v. Ames, 188

U.S. 321,321 (1903) (the Lottery Case).

64. J. EzELI., supra note 52, at 267-70.

65. Id. at 268-70.

66. N.H. Rev. Stat. ANN. $\$ 284$ (Repl. vol. 1987).

67. The Development of the law of Gambling, supra note 15 , at 678 .

68. Id.

69. Id. at 679 .
} 
than 60 percent of its revenues from taxes on horse racing, liquor, tobacco, and beer ${ }^{70}$ - but also suggested moral censure of the taxed activity.

A lottery, however, must be distinguished from a tax. Lotteries involve voluntary activities, whereas taxes are involuntary. Some politicians in the 1980 's seem to welcome legal gambling as a source of income that does not depend upon the coercive power of the state. ${ }^{71}$ The feature of raising money through a voluntary activity in lieu of taxation is for some a measure of gambling's moral worth in a society expressing an ideology of freedom of choice.

When the lottery was introduced in New Hampshire, 80 percent of the New Hampshire lottery tickets were sold to residents of New York, Massachusetts, and Connecticut, states that, at that time, did not have their own lotteries. ${ }^{72}$ To ease the burden of taxation within a state, exploitation of the moral weaknesses of out-of-state citizens became an acceptable alternative. During the nineteenth century, such exploitation helped terminate the Louisiana lottery, whereas in the twentieth century, other states, instead of castigating New Hampshire as an instrument of Satan, initiated their own lotteries. Recent lotteries, such as those adopted in California and Wisconsin, were understood to be directed primarily at an in-state market. ${ }^{73}$

Related to the issue of exploitation is the question of class bias in use of lotteries. Accordingly, class bias has been an issue when states have considered legalizing lotteries. ${ }^{74}$ The question is whether revenues from a lottery should be regarded as a regressive form of public finance. ${ }^{75}$ The lottery usually is a regressive source of public revenue because lower income individuals have the most incentive to play the games. ${ }^{76}$ Given a society with a wide disparity in the distribution of income, those on the lowest rung of the ladder value the possible winnings more than others. ${ }^{77}$ Some evidence suggests that lottery revenues are drawn more regressively than state sales taxes; opponents of lotteries have used that evidence as an argument against their use. ${ }^{78}$ Although class bias may be considered in assessing moral blameworthiness, other factors may be more significant.

Other opponents, drawing on a distinction between legalization and encouragement, argue that a state's mere sanction of an activity is more

70. Burke, The Evolution of State Lotteries, 8 Public Gaming 60, 62-63 (1961).

71. The Development of the Law of Gambling, supra note 15 , at 683.

72. Burke, supra note 70 , at 62-63.

73. For a more complete discussion of lottery growth, see Clotfelter \& Cook, Implicit Taxation in Lottery Finance, 40 NAT'L TAX J. 533 (1987).

74. See, e.g.. J. Skolnick, House of Cards: Legalization and Control of Casino Gambling 338-39, 342 (1978) (restricting access to gambling in Europe "presumably protecting the industrial working class from the temptations of gambling.")

75. Aranson \& Miller, Economic Aspects of Public Gaming, 12 ConN. L. Rev. 822, 836-37 (1980).

76. Id. at 838 .

77. The gambler himself may be said to be regressive. This may be viewed as a function of market impulses in the purchase of a consumer good. Id. at 835,838 .

78. Id. at 35 . 
acceptable than the use of advertising to stimulate demand. ${ }^{79} \mathrm{By}$ advertising, the interests of the state are pitted against the welfare of its citizens. The English have made that distinction in their policy on casino gambling and bingo. In England, such gaming establishments are regulated and permitted to exist, but they may not advertise. ${ }^{80}$ American states that have adopted the lottery do generally advertise. In any event, what had once been primarily a moral value conflict between aristocrats and Puritans has shifted to a conflict between a state's fiscal needs and a state's wishes not to exploit its citizens.

Although recognized to be exploitative and harmful, gambling has been increasingly used as a source of state revenue. ${ }^{81}$ According to surveys taken by the National Gambling Commission, an overwhelming majority of Americans have gambled, and do not regard the practice itself as sinful or immoral. ${ }^{82}$ Indeed, as crime rates rose sharply between 1960 and 1974, arrests for gambling declined by 67.7 percent. $^{83}$ In 1985 , wagering in legalized U.S. commercial gambling reached $\$ 159.16$ billion, with an estimated additional $\$ 31.65$ billion wagered illegally. ${ }^{84}$ Of that, gross revenues in the United States from the nation's casinos, racetracks, state lotteries, and other commercial games amounted to $\$ 20.9$ billion. ${ }^{85}$ Gross gambling revenues in 1985 exceeded that of U.S. Steel which reported $\$ 18.4$ billion in annual sales during the same year. ${ }^{86}$

As of April 1987, twenty-two states plus the District of Columbia had lotteries, and lotteries were being organized in five other states. ${ }^{87}$ Thirty-four states allow parimutuel betting on horse racing, and fifteen allow it on dog racing. ${ }^{88}$ The value conflict between aristocrats and Puritans seems to have been resolved, for now, in favor of these forms of gambling.

\section{V \\ Personal Familiarity}

Other factors can be suggested besides those discussed above to explain the process by which a particular vice becomes more or less acceptable. The

79. See generally J. Skolnick supra note 74, at 335-50 (comparing and contrasting the British and Nevada systems of gambling). Also, the U.S. Supreme Court held facially constitutional a Puerto Rico statute and regulation restricting advertising of casino gambling aimed at the residents of Puerto Rico. Posadas de Puerto Rico Assocs., DBA Condado Holiday Inn v. Tourism Co. of Puerto Rico, 478 U.S. 328 (1986).

80. J. SKolnick, supra note 74 , at 344,349 (author notes that a state's dependence on gambling for revenue results in a desire to seek ever-increasing profits and expansion).

81. Final Report, Commission on the Review of the National Policy Toward Gambling, Gambling in America 58 (1976) [hereinafter Final Report].

82. Id. at $58,69-70$.

83. Id. at 35 .

84. Christiansen, The 1985 Gross Annual Wager, Gaming \& Wagering Business, Aug. 1986, at 27 (citing 1985 U.S. gross gambling revenues at $\$ 20.9$ billion, compared to $\$ 18.4$ billion in sales for U.S. Steel).

85. Id.

86. Id.

87. Wisconsin Voters Authorize Lottery and Parimutuel Bets, N.Y. Times, Apr. 9, 1987, at A16, col. 1.

88. Id. at col. 2. 
long history of gambling in American society suggests some of these. Personal familiarity with an activity is an important factor. Thus, if an activity is socially isolated, it more likely will be perceived as illegitimate. Gambling has long been part of the culture of the United States, even though it has been defined as immoral by fundamentalist churches and Pentecostal sects. ${ }^{89}$ Whatever the norms forbidding gambling might have been, most Americans participate in these activities or know people who do. ${ }^{90}$ The familiarity of the activity tends to "normalize" it, and therefore to produce an ideology of legitimization. For example, in Las Vegas, blackjack dealing is perceived as a normal and respectable activity, whereas, in other communities blackjack dealing might appear rather shady. ${ }^{91}$

Even illegal activity can become normalized through familiarity. Criminological and popular writing is replete with reports of prostitutes, ${ }^{92}$ mobsters, ${ }^{93}$ con-men, ${ }^{94}$ price-fixers, ${ }^{95}$ thieves, ${ }^{96}$ and fences, ${ }^{97}$ all of whom carne to accept their respective activities as unremarkable. A comparison between attitudes toward gambling and the use of drugs further illustrates how familiarity can legitimize an activity. Until the 1960's, when the use of marijuana became popular on college campuses, ${ }^{98}$ most Americans were familiar with gambling and unfamiliar with drugs or their users. ${ }^{99}$

\section{VI}

\section{Social Status}

Like familiarity, social status of those engaging in an activity affects the acceptability of an activity. ${ }^{100}$ If the social status of those engaging in an activity is high, then the activity will more likely be perceived as legitimate. ${ }^{101}$ For example, drug use, until the 1960's, was associated with identifiable

89. See Bell, Moral Views on Gambling Promulgated by American Religious Bodies, in CoMmmission on the Review of the National Policy Toward Gambling, Staff and Consultant Papers 161-259, app. 1 (1976).

90. Final RePort, supra note 81 , at 58.

91. Las Vegas has a sizeable Mormon population, many of whom work for casinos. Mormons are not, however, permitted to work as dealers in table games. They are allowed to work in any support occupation such as accountants, security guards, or cocktail waitresses. See J. SкоLNick, supra note 74 , at 152 .

92. See, e.g., S. Barrows \& W. Novak, Mayflower Madam: The Secret Life of Sydney Biddle BARROWS (1986).

93. See, e.g., N. Pileggi, Wiseguy: The Rise and Fall of a Mobster (1986).

94. See, e.g., D. Maurer, The Bic Con (1940).

95. See, e.g.. Ross, How Lawless are Big Companies?, Fortune, Dec. 1, 1980, at 56-64.

96. See, e.g., E. Sutherland, The Professional Thief (1937).

97. See, e.g., C. Klockars, The Professional Fence (1974).

98. B. Johnson, Marijuana Users and Drug Subcultures 1 (1973).

99. See Fact Research, Inc., Gambling in Perspective: A Review of the Written History of Gambling and an Assessment of its Effect on Modern American Society, in Commission on the Review of the. National Policy Toward Gambling, supra note 89, at 1-101.

100. J. Himmelstein, supra note 7 , at 3.

101. Himmelstein writes: "The higher the social status of the actors, the less likely that their actions will be stigmatized and regarded as deviant." Himmelstein, The Continuing Career of Marijuana. Backlash Within Limits, Contemp. Drug Probs. Spring 1986, at 1-2. 
minority groups. ${ }^{102}$ As David Musto (and others) have found, "[ $\left.t\right]$ he most passionate support for legal prohibition of narcotics has been associated with fear of a given drug's effect on a specific minority."'103 Thus, some people thought that opium facilitated sexual contacts between Chinese and white Americans, marijuana incited Chicanos to violence, cocaine empowered blacks with the ability to withstand bullets and to enhance their sexual powers, and heroin caused ghetto youth gangs. ${ }^{104}$ Gambling, unlike drugs, spanned across the social structure. Except for the very poor, the elderly, and those belonging to bible-oriented sects, most Americans have some betting experience. ${ }^{105}$ According to the National Gambling Commission, however, blacks are arrested for gambling offenses at a substantially higher rate than whites or others, ${ }^{106}$ suggesting that, as with drugs, the moral blameworthiness of an activity is influenced by the social status of those who participate in the activity. ${ }^{107}$

\section{VII}

\section{Conventionality of Lifestyles}

Conventionality of the lifestyle is another factor affecting conceptions of moral blameworthiness. Those who play the lottery, frequent casinos, and bet on the Superbowl ordinarily follow traditional lifestyles. Marijuana users, however, even those during the 1960's whose social status was middle class or above, might have been perceived as rebellious, dirty hippies. ${ }^{108}$ As the use of marijuana spread to the middle class and as people who experienced marijuana in college began to move out to conventional and high status professions, marijuana use became more acceptable. ${ }^{109}$ As this occurred, marijuana use was no longer seen as the exclusive province of ghetto blacks, Hispanics, and hippies, and an ideology of legitimization began to develop. Those in favor of marijuana legalization said it was equally as or less harmful

102. J. Himmelstein, supra note 7 , at $46-47$.

103. D. Musto, The American Disease: Origins of Narcotic Control 244 (1973).

104. Id.

105. Final RePORT, supra note 81 , at $\mathbf{5 9}$.

106. Id. at $34-38$.

107. Lindesmith argues that marijuana owes some of its moral blameworthiness to its original association with the "lower" classes. Himmelstein, Drug Policies Theory: Analysis and Critique, $8 \mathrm{~J}$. DRUG Issues 37-38 (1978) (citing A. Lindesmith, The Addict and the LaW (1965)).

108. J. KAPLAN, supra noce 32 , at 5,7 .

109. Jerome Himmelstein describes this process as follows:

[t]he spread of marijuana to middle-class youth meant that the average socioeconomic position of the late 1960's, early 1970's marijuana users was significantly higher than that of previous users of marijuana and narcotics. This had three important ramifications. First, youthful middle-class users were relatively powerful. Although they did not decisively shape policy, they did put together an organized, educated, vociferous constituency that commanded significant attention. Second, the users were respectable. Independent of any action they took, their middle-class position gave them a relatively high status honor. Third, they were relatively accessible to policymakers and writers. For the first time, the latter had an opportunity to see them as total human beings, not merely drug users.

J. Himmelstein, supra note 7, at 106. 
than alcohol and that equity pointed to legalization.110 Although the decriminalization movement did not entirely succeed, several states adopted a policy of labelling the use of small amounts (less than an ounce) as an infraction while possession of marijuana for sale was retained as a felony. ${ }^{111}$ The increased use of the drug by the socially respected influenced its acceptance as a morally safe substance. ${ }^{112}$ Public opinion forced a gradual shift in the official response to marijuana use. ${ }^{113}$

\section{VIII}

\section{Protection of The Young}

The perceived effect of an activity on the young is another factor which appears to influence conceptions of legitimacy and moral blameworthiness. Protection of children is one of society's highest collective values, over which little conflict exists. ${ }^{114}$ Although liberals and fundamentalists may find themselves on opposite sides on the issue of pornography, ${ }^{115}$ once children are involved, society offers little or no moral acceptance. ${ }^{116}$ If a vice implicates the young, it will more likely be defined as morally blameworthy.

Of all the vices, legal gambling is probably least available to the young. ${ }^{117}$ The relationship between legal vice and age of consent is interesting. In general, minors are thought to lack the capacity to give informed consent for various activities which, when performed by adults, may be acceptable. States have different ages of consent to heterosexual activities, but there is always a distinction between an adult and a minor. ${ }^{118}$

Thus, even if society were to decriminalize marijuana use, sale to minors almost certainly would be prohibited. Although middle class use made marijuana more acceptable, its use by high school students doubtless made it

110. J. KAPLAN, supra note 32, at 290-91.

111. R. Schroeder, The Politics of Drugs: An American Dilemma 21-25 (2d ed. 1980).

112. Id at 15 (chapter entitled Shift in Attitude Toward Marijuana, identifying some well-known Americans who have tried marijuana).

113. Id. at 21 .

114. See R. Mnookin, Child, Family, and State: Problems and Materials on Children and THE LAW 2-3 (1978).

115. See Bryden, Between Two Constitutions: Feminism and Pornography, 2 Constitutional Commentary $147,175-77$ (1985).

116. The U.S. Supreme Court has stated that: "[i]t is evident beyond the need for elaboration that a state's interest in 'safeguarding the physical and psychological well-being of a minor' is 'compelling." New York v. Ferber, 458 U.S. 747, 757 (1982) (citing Globe Newspaper Co. v. Superior Court, 457 U.S. 596, 607 (1982)). See also Ginsberg v. New York, 390 U.S. 629 (1968) (upholding conviction for selling obscene materials to a minor on basis that it was constitutionally permissible for state to accord a minor a more restricted right than those assured to adults to decide for themselves what materials they may read or see).

117. My own observations of casino gambling suggest that casinos are careful to exclude minors from table games such as craps, blackjack, and baccarat. Casino table games and slot machines are intensively observed by various designated observers such as pit bosses and security police. See J. SkOLNICK, supra note 74, at 239-57. Obviously, slot machines located in grocery stores are not as carefully observed as those located in casinos. In general, when deviant conduct can be performed surreptitiously it is much more difficult to control.

118. See, e.g., Cal. Penal Code $\$ 261.5$ (West Supp. 1988) (unlawful sexual intercourse with female under 18). 
less so. Before the mid-1960's, marijuana use was confined mainly to the urban underprivileged, and to "certain insulated social groups" such as jazz musicians and artists. ${ }^{19}$ By 1975, one survey reported that more than 40 percent of high school seniors had used the drug. ${ }^{120}$ By 1980,60 percent of high school students surveyed nationally indicated that they had tried smoking marijuana. ${ }^{121}$ The spread of marijuana use to the young explains the concerns of an older, parental generation. Ironically, that spread may also increase the familiarity of marijuana, resulting in further redefinition of the moral blameworthiness of its use. In any event, the cultural value of protecting the young must be part of our analysis of moral ambivalence and of any policy analysis of vice.

IX

\section{Potency and Dependency of the Vice}

Marijuana's rapid spread suggests another factor influencing moral ambivalence, that being the potency or hardness of the vice. This characteristic of vice may cause the actor's energies to focus on the vice, to the exclusion of other obligations or responsibilities. Moral blameworthiness, from this perspective, derives from a person's addiction and resulting incapacity to set priorities properly. Persons who spend all their time "looking for action" or seeking to "score some dope" are said to be dependent or addicted, ${ }^{122}$ and their energies could be put to more productive use.

Since 1964, marijuana has become a harder drug and therefore more addicting. During the 1960 's, most of the marijuana imported into the United States was grown in Mexico and had a relatively low percentage $(0.5$ percent to 2.00 percent) of tetrahydrocannabinol ("THC"), marijuana's active ingredient. ${ }^{123}$ To prevent marijuana abuse, the Nixon Administration cut off sizeable proportions of the Mexican supply through "Operation Intercept." 124 This program involved searches at the San Ysidro checkpoint

119. The National Commission on Marijuana and Drug Abuse, First Report, Marijuana: A Signal of Misunderstanding 7 (Mar. 1972).

120. Id.

121. Id.

122. Although there is no single agreed upon definition of drug addition or alcoholism in current scientific or medical literature, Levine cites the World Health Organization's 1957 Expert Committee on Addiction Producing Drugs' definition as being widely used. That definition is:

[d]rug addiction is a state of periodic or chronic intoxication produced by repeated consumption of a drug (natural or synthetic). Its characteristics include: (1) an overpowering desire or need (compulsion) to continue taking the drug and to obtain it by any means; (2) a tendency to increase the dose; (3) a psychic (psychological) and generally a physical dependence on the effects of the drug; (4) detrimental effect on the individual and society.

Levine, The Discovery of Addiction: Changing Conceptions of Habitual Drunkenness in America, 39 J. STUD. Alcoноl 143, 167 (1978). Obviously, "obtained by any means" has to be questioned. Although addicts may be willing to use unlawful means to obtain drugs it is doubtful that all will use "any means" necessary.

123. Interview with Charles Stowell, State of California Marijuana Coordinator for Drug Enforcement Administration (Feb. 1988).

124. Id. 
of weekend travelers to Mexico and a policy of destroying Mexican marijuana fields with the poison paraquat. ${ }^{125}$ Although the two pronged assault discouraged the importation of marijuana from Mexico, it did not discourage marijuana use. ${ }^{126}$ While the Mexican variety declined, marijuana with a heightened THC content of 5 to 6 percent appeared in large quantities from Columbia, Panama, and Thailand. ${ }^{227}$ In addition, enterprising Californians planted substantial crops of a potent variety called sensimilla, containing $\mathbf{8}$ to 12 percent THC. ${ }^{128}$ The Drug Enforcement Administration currently estimates that sensimilla contains 12 to 18 percent THC. ${ }^{129}$ Thus, wellintentioned efforts to intercept marijuana resulted in the unintended consequence of "hardening" the drug. Although the negative effects of marijuana are debatable, a drug with many times the THC content may well be more deleterious than a lighter variety.

Hardness of a vice may interplay with other elements, such as the ages of participants, in shaping perceptions of the vice. Because drug hardening occurred as the ages of users shifted downward, values of protecting the young combined with this increased hardness to strengthen attitudes against drug use. This is illustrated in the case of cocaine, which has hardened into the distillable called "crack" or "rock." In fact, during the 1980's, distinctions among a variety of drugs seemed increasingly less important as young people were advised to "Just Say No" to all forms of drug abuse.

As with drugs, hardness of gambling is a factor in assessing its moral blameworthiness. Classic lotteries were soft because they had a periodic character, with the drawing occurring only once a week, or even annually. ${ }^{130}$ Modern lotteries, such as the one in California, are harder because they include instant games and payoffs, making them more akin to slot machines. Nevertheless, since gamblers purchase their tickets in supermarkets and gas stations, the ambience of the lottery is less conducive to heavy gambling than the atmosphere of a casino.

Casinos, by contrast, are psychologically programmed to induce gambling. ${ }^{31}$ Thus, the hotel portion of a casino hotel is typically constructed to require the guest to pass by the tables on his or her way to the outer doors. ${ }^{132}$ The casino itself is a timeless place with no visible clocks or windows. ${ }^{133}$ The casino also caters to satisfy other needs of customers, such

125. Id.

126. Id.

127. Id.

128. Interviews with vice enforcement officers, Oakland Police Department, Oakland, California (1986).

129. The scale in terms of which THC context is measured increases geometrically rather than arithmatically. Thus, the shift from $2 \%$ to $18 \%$ produces a drug with approximately fifty times the potency. Id.

130. Prior to the advent of the three-number combination system of lottery drawing, drawings could continue for months at a time. Final RePORT, supra note 81, at 145.

131. See J. SKolnick, supra note 74 , at 36 .

132. Id.

133. Id 
as food and drink, so as to discourage departure and encourage play. ${ }^{134}$ Even the music in the elevators may be programmed, with lively music for the down part of the ride, as the resident customer is about to enter the casino, and soothing music for the return ride to the room. ${ }^{135}$ Therefore, the lottery is a "softer" form of play than casino gambling, and is less likely to invite negative assessments of moral blameworthiness.

\section{$\mathrm{X}$ \\ Perceived Controllability}

The notion of perceived controllability is another factor affecting the moral acceptability of an activity. The Jamestown lottery was discontinued when it was discovered that its receipts were being siphoned off by those who ran the lottery. ${ }^{136}$ Since lotteries have become so widely accepted, proponents of modern lotteries have apparently convinced the general public that they would be run fairly. Similarly, modern parimutuel betting also appears to be considered fair and controllable. In contrast, considerable skepticism exists about the capacity of administrative agencies to police the casino industry. ${ }^{137}$ Casino gambling carries the stigma of association with organized crime, whereas lotteries do not. ${ }^{138}$ For this reason, some states have decided not to legalize casinos, fearing government corruption and involvement of organized crime. ${ }^{139}$ Thus, an activity that is perceived as uncontrollable will more likely be viewed as undesirable.

\section{XI}

\section{Public-Private Distinction}

Moral ambivalence toward vice is also related to a distinction between public and private behavior. Society permits a public show of affection between a man and a woman but public sexual intercourse is considered an affront to public decency. ${ }^{140}$ Similarly, in some circles adultery committed discreetly may be considered more acceptable than when committed publicly. Richard Sennett argues that society has deemphasized the importance of public gathering places. ${ }^{141}$ This argument, however, does not apply to the less affluent who lack the resources needed to control private space. For them, civility of public space is increasingly meaningful. For example,

134. Id.

135. Interview with Shannon Bybee, Casino Executive, Golden Nugget Casino, Las Vegas, Nevada (Apr. 1984).

136. J. EzELL, supra note 52, at 4-8, 15.

137. J. Dombrink, Outlaw Businessmen: Organized Crime and the Legalization of Casino Gambling 35, 284-86 (1981) (unpublished Ph.D. dissertation, Department of Sociology, University of California at Berkeley).

138. See J. Skolnick, supra note 74, at 124 .

139. See J. Dombrink, supra note 137.

140. As H.L.A. Hart says: "Sexual intercourse between husband and wife is not immoral, but if it takes place in public it is an affront to public decency." H. HART, supra note 1 , at 45.

141. R. Sennett, The Fall of Public Man 251 (1974). 
members of community groups in affluent Marin County, California, have not vigorously petitioned police and prosecutors about drug use, whereas people in Oakland, California, have shown their concern. ${ }^{142}$ Both places are reputed as centers of substantial drug use. ${ }^{143}$ In Oakland, however, certain neighborhoods have experienced considerable street drug dealing and use, which in turn has resulted in a public outcry against drugs. Law enforcement officials have suggested that Oakland residents do not find drug use per se morally offensive. Rather, these residents are concerned about the spillover of drugs into the streets and the associated violence this will cause. ${ }^{144} \mathrm{~A}$ pattern of drug dealing, and street violence catapults drug use from the status of mere vice into that of serious crime.

Prostitution offers another illustration of tolerance for a private but not public activity. Many cities have quietly run brothels, the existence of which neighbors may not be aware. ${ }^{145}$ Further, some massage parlors offer sexual services which are not objected to by neighbors, provided that these services are offered discreetly. ${ }^{146}$ Berkeley, California, in response to appeals from local neighborhood groups and the City Council, has cracked down on street prostitution. ${ }^{147}$ Similarly, residents of West Oakland, a largely black residential area bordering parts of Berkeley, have organized marches to eliminate prostitution. ${ }^{148}$ Marchers carried picket signs reading "[w]e are victims of prostitution," and chanted "[w]e shall overcome."149 Again, the marchers were not concerned primarily about the moral probity of sex for sale. Rather, they were concerned about solicitation on the streets and any adverse influence that this would have on their neighborhood and their children. Therefore, prostitution in large cities may be tolerated when it occurs privately and does not penetrate the public domain. When vice assumes a public character, private lives may involuntarily be affected. This invites public denunciation.

142. Interview with George Neispolo, Assistant U.S. Attorney, San Francisco, Cal. (Jan. 1986). Neispolo commented, "there are probably more drugs used in Marin County than there are in Oakland but there isn't anything like the same visibility."

143. Id.

144. The physical danger felt by Oakland residents from drug dealing is made vivid by homicide statistics. From 1980 to 1986,141 of 671 killings have been classified as "drug-related" by Oakland's homicide squad.

Moreover, for every Oakland drug-related homicide victim, police and prosecutors interviewed in 1986 estimate eight to ten shootings per homicide victim. A sergeant who investigates felonious assaults says he can make no reliable estimate. He is probably right. But we do know there have to be substantially more drug-related shootings than drug-related homicides. Those who shoot often miss the target, select the wrong target, or wound rather than kill. If we do estimate ten shootings per killing, there were somewhere around 1,500 drug-related shootings in Oakland in a five year period. Whatever the actual figure, there can be little doubt that, more than any other factor, the killings and the shootings, the violence and the threat of violence, has in Oakland transformed the perception of drug distribution and sale from a victimless to a serious crime. J. Skolnick, Policing Drugs: The Cultural Transformation of a Victimless Crime 7-8 (1986) (unpublished manuscript).

145. S. Barrows \& W. Novak, supra note 92 .

146. R. Rosen, The Lost Sisterhood: Prostitution in America, 1900-1918, at 176 (1982).

147. Id. at 177 .

148. Id. at 176.

149. Id. 


\section{XII \\ Leaders, Social Policy, and Vice}

Perceptions of a vice are also affected by the efforts of a society's leaders. This is seen in the case of drugs where moral questions ${ }^{150}$ over drug abuse and the political weakness of drug users provide a dangerously open field for bureaucrats. Edward J. Epstein's study of the Office of Drug Abuse Law Enforcement (ODALE) discussed two aspects of such politics, one at the federal and one at the state level. ${ }^{151}$ ODALE was established on January 27, 1972, by an executive order of President Nixon and without approval or consideration of Congress. ${ }^{152}$ Technically, the office operated out of the Department of Justice, but its director also had an office in the executive offices of the President. ${ }^{153}$ ODALE was empowered by presidential order to requisition agents from other federal agencies, including the Bureau of Narcotics and Dangerous Drugs, the Bureau of Customs, the Internal Revenue Service (IRS), and the Bureau of Alcohol, Tobacco and Firearms, as well as to redeploy these agents into strike forces. ${ }^{154}$ These strike forces were empowered to use court authorized wiretaps and no-knock warrants as well as searches incidental to arrest procedures. ${ }^{155}$ They could also feed suspects to a target selection committee in the IRS that would initiate its own audits and investigations. ${ }^{156}$ Epstein argued that,
as long as President Nixon could focus the attention of Congress and the press on the "menace" of heroin addiction destroying America, the hope was that this new office could execute his orders free of any normal restraints from the "bureaucracy," from Congressional committees, and from the press, which normally reported only the stories presenting the government's statistics in the war against drugs. ${ }^{157}$

The power of this new instrument thus depended directly on the continued organization of fear by the White House. ${ }^{158}$

Thus, behind my argument lurks another, about the limits of rationality of social policy analysis regarding vices. The point is that neither data nor expert pronouncements are dispositive in areas so heavily laden with symbolism and social evaluations associated with moral ambivalence. An objective fiscal analysis can predict how much money will flow to the state should a lottery be introduced, but a lottery can be neither established nor disestablished absent a very considerable moral judgment on the part of voters. How do people come to accept or reject the idea that it is permissible for the state to urge its citizens to bet on a lottery? The answer cannot be

150. Stanley Cohen has described society's "moral panic" as the emergence of a condition, episode, person or group of persons defined as a threat to societal values and interest. S. CoHEN, Folk Devils and Moral Panic: The Creation of the Mods and the Rockers 9 (1972).

151. E. Epstein, Agents of Fear: Opiates and Political Power in America (1977).

152. Id. at 19 .

153. Id.

154. Id.

155. Id.

156. Id at 19-20.

157. Id. at 20.

158. Id. 
fiscal necessity alone. If that were true society should legalize and tax popular illegal drugs such as marijuana as it does alcohol and tobacco.

Similarly, moral judgments about the nature of community heavily influence how society thinks about drugs and drug policy. How do people come to accept the idea that a policy of imposing increasingly heavy criminal penalties for drug sales, plus a policy of interdiction, is the appropriate direction for solving or even reducing the drug problem? The answer cannot be that such policies are rational and scientific. Our moral ambivalence regarding vice, it is suggested, elicits strong cultural and symbolic meanings that heavily influence how society regards the phenomenon.

Suppose the Bolivian cocaine fields could be destroyed and the flow of 90 percent of the cocaine traffic to the United States could be cut off. Would that solve the drug problem or make it even worse? In the background are the much more potent synthetic "designer" drugs that might replace cocaine. Fentanyl, for example, is 100 times as strong as morphine and twenty to forty times as strong as heroin. ${ }^{159}$ Fentanyl's medicinal analogues, sufentanyl and lofentanyl, are 2,000 and 6,000 times stronger than morphine. ${ }^{160}$ These drugs act very rapidly and their effects last thirty to sixty minutes. ${ }^{161}$ Some anesthesiologists believe that addiction can occur after one injection. ${ }^{162}$ Moreover, those trained in faster living through chemistry can synthesize these powerful narcotics relatively inexpensively and with readily available materials. Nor will drug testing necessarily detect users. Physicians are advised to suspect fentanyl use in patients if they see all the signs and symptoms of narcotic addiction, but find no evidence of drugs in blood or urine. Moreover, since these substances may be inhaled, needle marks may not be visible. ${ }^{163}$ Even with the huge amounts of money allocated to interdiction, efforts to eliminate agricultural drugs have failed. If interdiction efforts were to succeed, however, society might be facing a designer drug problem more potent and destructive than the contemporary problem.

Similarly, police departments around the country are increasingly arresting large numbers of small time dealers instead of concentrating on carefully planned investigations aimed at larger suppliers. ${ }^{164}$ Narcotics law enforcers have learned that a policy aimed at apprehending larger dealers is not particularly effective. It may even backfire as it did in Oakland, California, where a careful and sustained joint local and federal effort resulted in the conviction of Oakland's three major drug dealers in 1985. There was virtually no decline in drug dealing, but there was a rise in street shootings and drugrelated homicides. In effect, the successful convictions had apparently destabilized the illegal distribution system and generated violent street

159. Ziporyn, A Growing Industry and Menace: Makeshift Laboratory's Designer Drugs, 256 J.A.M.A. 3061 (1986).

160. Id.

161. Id.

162. Id

163. Id

164. Kerr, War on Drugs Shifting Focus to Street Deals, N.Y. Times, Apr. 13, 1987, at Al, col. 5. 
conflict over succession to the lucrative market. The point is not whether "buy and bust" tactics or efforts toward convicting major drug dealers will in any sense "solve" the drug problem. No carefully planned research has elected the policy shift toward street level enforcement. Indeed, there is considerable disagreement about the long term effectiveness of this strategy. More to the point, drug law enforcement efforts are primarily significant for what they symbolize. "Buy and bust" tactics are far more visible to residents of neighborhoods in which street drug sales occur and therefore signify concern by police and other public officials for the integrity of the neighborhood. They are symbolically effective even when they have little impact on the prevalence of street drug dealing. Such tactics make no sense at all when drug sales occur among the affluent, in private.

\section{XIII}

\section{Conclusion}

Although society requires a core of normative consensus, we often find considerable ambivalence about peripheral norms. The phenomenon of vice, which represents both pleasure and wickedness, reflects the moral ambivalence located at the periphery. As a result, we can be confident that attitudes toward vice are prone to change. Shifting attitudes can be dramatic, as occurred in the case of gambling and drugs in the past two decades. In 1964, no lotteries existed in the United States. ${ }^{165}$ Today, lotteries are found in a wide variety of states, largely for the purpose of raising revenue. ${ }^{166}$ This paper attempts to identify what seem to be especially salient social and symbolic factors associated with acceptance, on one hand, and increasing fear and moral panic on the other.

In a pluralistic society, conflicting opinions of the acceptability of vice are affected by the rise and fall of Puritan values, government fiscal needs and pressures, freedom of choice, and government exploitation of moral weakness. Other factors that independently affect the moral acceptability of vice include personal familiarity with the activity, social status of the user, conventionality of lifestyles, desire to protect the young, potency of the vice, perceived controllability, private-public distinction, and effects brought about by a society's leaders and their policies. In sum, when we think about vice policy and the limits of policy analysis, we must maintain a continuing awareness of the very considerable moral ambivalence activating law and policy associated with vice. A sociological understanding tells us that what is defined as a problem-and as a solution-will most often depend on ideologies grounded in cultural contexts and symbolic functions ${ }^{167}$ rather than on scientific hypotheses and empirical research.

165. Final RePORT, supra note 81 , at 144.

166. 26 States Now Running Lotteries to Ease Budgetary Burdens, supra note 14.

167. See McConahay, supra note 21. 
